\title{
The Endocannabinoid System as a Potential Therapeutic Target for Pain Modulation
}

\author{
Ahmet Ulugöl \\ Department of Medical Pharmacology, Trakya University Faculty of Medicine, Edirne, Turkey
}

\begin{abstract}
Although cannabis has been used for pain management for millennia, very few approved cannabinoids are indicated for the treatment of pain and other medical symptoms. Cannabinoid therapy re-gained attention only after the discovery of endocannabinoids and fatty acid amide hydrolase (FAAH) and monoacylglycerol lipase (MAGL), the enzymes playing a role in endocannabinoid metabolism. Nowadays, research has focused on the inhibition of these degradative enzymes and the elevation of endocannabinoid tonus locally; special emphasis is given
\end{abstract}

on multi-target analgesia compounds, where one of the targets is the endocannabinoid degrading enzyme. In this review, I provide an overview of the current understanding about the processes accounting for the biosynthesis, transport and metabolism of endocannabinoids, and pharmacological approaches and potential therapeutic applications in this area, regarding the use of drugs elevating endocannabinoid levels in pain conditions. (Balkan Med J 2014;31:115-20).

Key Words: 2-AG, anandamide, endocannabinoids, FAAH, MAGL, pain
Cannabinoids are a group of chemical compounds that produce their effects via activating cannabinoid receptors; they include the phytocannabinoids (herbal cannabinoids/natural cannabinoids found in the cannabis plant), synthetic cannabinoids, and endogenous cannabinoids (endocannabinoids) $(1,2)$. Cannabis, also known as marijuana, has been used as both a recreational and medicinal drug for centuries. Pain management is the most important among the medicinal purposes, and has been drawing intense attention following the discovery of cannabinoid receptors and their endogenous ligands, endocannabinoids (3-5). $\Delta^{9}$-tetrahydrocannabinol (THC) and cannabidiol, the critical components of the cannabis plant, and the synthetic cannabinoids and their analogues have been shown to exert strong analgesic action both in preclinical and clinical studies (6-9). In this review, after a brief introduction to cannabinoid receptors, phytocannabinoids and synthetic cannabinoids, I provide an overview of what is currently known about the synthesis, release, degradation and biological actions of endocannabinoids, regarding their role in pain modulation, and describe the recent evidence of the promising results of augmentation of endogenous cannabinoid tonus for the treatment of pain.

\section{CANNABINOID RECEPTORS AND THE SITE OF ACTION OF CANNABINOIDS}

To date, two subtypes of cannabinoid receptors, termed cannabinoid-1 $\left(\mathrm{CB}_{1}\right)$ and cannabinoid-2 $\left(\mathrm{CB}_{2}\right)$ receptors, have been cloned $(10,11) . \mathrm{CB}_{1}$ receptors are most abundantly expressed in the central nervous system (CNS), most densely in motor and limbic regions, and in areas that are involved in pain transmission and modulation, such as periaqueductal grey (PAG), rostral ventromedial medulla (RVM), spinal cord dorsal horn, and in the periphery. $\mathrm{CB}_{1}$ receptors are generally located pre-synaptically on axons and terminals of neurons and mediate the inhibition of neurotransmitter release by the inhibition of adenylate cyclase, blockade of voltage-dependent calcium channels, and/or by the activation of potassium channels and mitogen-activated protein kinase. $\mathrm{CB}_{2}$ receptors, on the other hand, are found mainly, but not exclusively, outside the CNS, predominantly in peripheral tissues with immune functions, and most densely in the spleen. Similar to $\mathrm{CB}_{1}$ receptors, $\mathrm{CB}_{2}$ receptors are also G-protein coupled, inhibits adenylate cyclase and produce cellular inhibition, but neither blockade of calcium channels 
nor activation of potassium channels mediates this inhibitory effect (Figure 1) (1, 2, 12-14).

Phytocannabinoids, synthetic cannabinoids and endocannabinoids are thought to produce their anti-nociceptive action primarily through $\mathrm{CB}_{1}$ receptors, located at the supraspinal, spinal and peripheral levels $(15,16)$. Activation of descending inhibition by presynaptic inhibition of GABAergic and glutamatergic transmission in the PAG and modulation of on- and off-cells in the RVM seems to play pivotal roles in supraspinal analgesia $(15,17,18)$. $\mathrm{CB}_{1}$ receptors found in presynaptic afferent terminals and on the terminals of intrinsic neurons and efferent supraspinal neurons are likely to mediate antinociception at the spinal level $(15,17)$. Topical cannabinoid anti-nociception and its synergy with spinal sites have also been suggested (19). $\mathrm{CB}_{2}$ receptors, although not as extensively studied as the $\mathrm{CB}_{1}$ receptors, are also proposed to play a role in the anti-nociceptive effects of cannabinoids (20).

\section{PHYTOCANNABINOIDS AND SYNTHETIC CANNABINOIDS}

Almost 80 of the chemical compounds in the cannabis plant, named phytocannabinoids, have the structure of a cannabinoid. Of these, THC is the best characterised and the primary psychoactive component of the plant. THC has an impact on many pathophysiological processes, including anti-nociception, through the activation of $\mathrm{CB}_{1}$ and $\mathrm{CB}_{2}$ receptors. However, its clinical utility is limited due to its unwanted CNS effects, which are mediated via brain $\mathrm{CB}_{1}$ receptors $(5,14)$. Cannabidiol, another important phytocannabinoid gaining attention recently, has a very low affinity at $\mathrm{CB}_{1}$ and $\mathrm{CB}_{2}$ receptors. Unlike THC, it does not cause any psychoactivity, but exerts many positive pharmacological effects, including anti-anxiety, anti-epileptic, anti-bacterial, anti-inflammatory, anti-cancer and anti-diabetic properties $(14,21,22)$. In addition to its wide therapeutic spectrum, cannabidiol is proposed to reverse some of the central side effects of THC (21-23). Nabiximols $\left(\right.$ Sative $\left.^{\circledR}\right)$, a herbal cannabis extract containing THC and cannabidiol at a 1:1 ratio in an oromucosal spray, has been approved for the treatment of neuropathic pain and spasticity associated with multiple sclerosis and intractable cancer pain (24).

Dronabinol $\left(\right.$ Marinol $\left.^{\circledR}\right)$, a synthetic THC, and its analogue nabilone $\left(\right.$ Cesamet $\left.^{\circledR}\right)$ are the currently available synthetic cannabinoids. Dronabinol and nabilone have been approved for chemotherapy-associated emesis in Canada and USA for many years. In addition, nabilone is indicated for anorexia associated with AIDS-related weight loss $(14,25)$. Recently, a clinical trial regarding the efficacy of nabilone in diabetic neuropathy has also ended in success (26). Rimonabant, a $\mathrm{CB}_{1}$ receptor antagonist/inverse agonist, was approved for

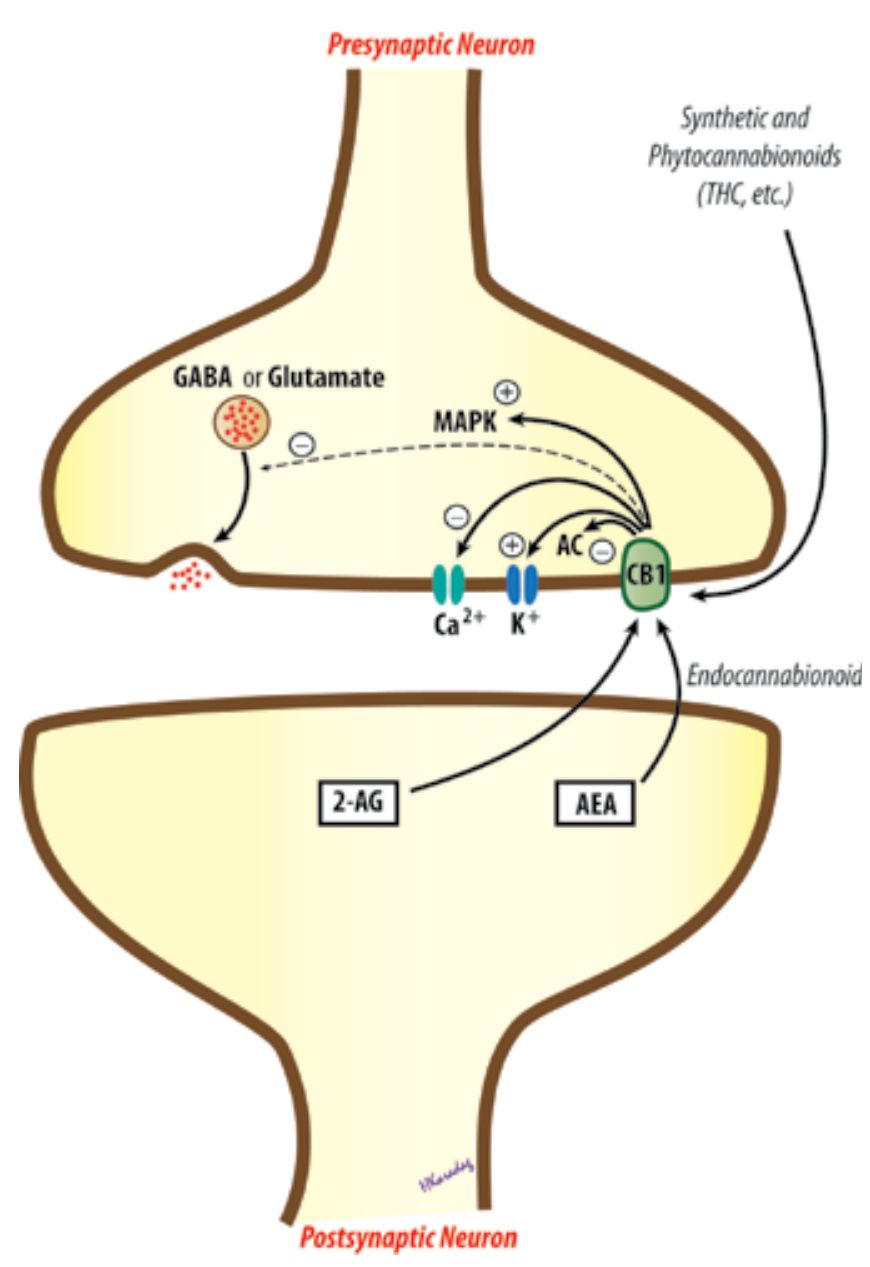

FIG. 1. Transduction mechanisms for cannabinoid $C_{1}$, receptors. $A C$, adenylate cyclase; $A E A$, arachidonyl ethanolamide, anandamide; 2-AG, 2-arachidonylglycerol; $\mathrm{CB}_{1}$, cannabinoid receptor 1; GABA, gamma-aminobutyric acid; MAPK, mitogen-activated protein kinase; THC, tetrahydrocannabinol.

obesity and smoking cessation, but withdrawn because of the increased incidence of depression.

\section{ENDOCANNABINOIDS: SYNTHESIS, RELEASE, TRANSPORT, AND METABOLISM}

The endocannabinoid system is comprised of cannabinoid $\mathrm{CB}_{1}$ and $\mathrm{CB}_{2}$ receptors, endogenous agonists of these receptors, "endocannabinoids", and the processes playing a role in biosynthesis, release, transport and metabolism of these endogenous lipid-signalling molecules. Arachidonyl ethanolamide (AEA, anandamide), 2-arachidonylglycerol (2-AG), $\mathrm{O}$-arachidonyl ethanolamine (virodhamine), $\mathrm{N}$-arachidonyl dopamine (NADA), and 2-arachidonyl glyceryl ether (noladin ether) are the putative endocannabinoids. Of these endogenous metabolites of eicosanoid fatty acids, AEA and 2-AG 

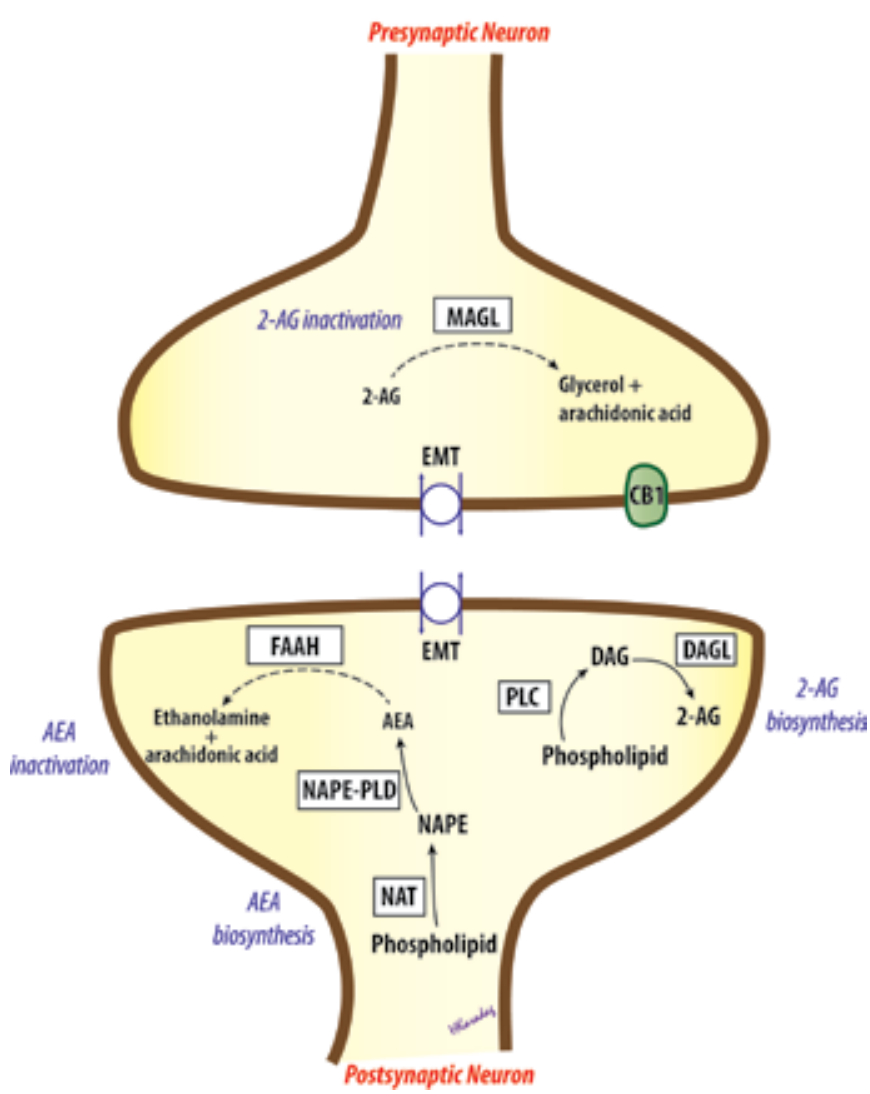

FIG. 2. Biosynthesis and inactivation of endocannabinoids. AEA, arachidonyl ethanolamide, anandamide; 2-AG, 2-arachidonylglycerol; CB1, cannabinoid receptor 1; DAG, diacylglycerol; DAGL, diacylglycerol lipase; EMT, endocannabinoid membrane transporter; FAAH, fatty acid amide hydrolase; MAGL, monoacylglycerol lipase; NAPE, N-acylphosphatidylethanolamine; NAPE-PLD, NAPE-selective phospholipase D; NAT, N-acyltransferase; PLC, phospholipase C.

are the best characterised $(4,5,14)$. Endocannabinoids activate $\mathrm{CB}_{1}$ and/or $\mathrm{CB}_{2}$ receptors to modulate physiological and pathological conditions, including memory, appetite, immune function, sleep, stress response, thermoregulation, addiction, and no wonder analgesia. AEA and NADA are also shown to have an affinity to transient receptor potential vanilloid 1 (TRPV1) receptors $(4,14,27)$.

Endocannabinoids are highly lipophilic compounds that are not stored in vesicles after production. Unlike classical cannabinoids, such as THC, they are substantially synthesised "on demand" from membrane phospholipids, and released immediately. Both AEA and 2-AG are produced at post-synaptic neurons. A two-step process is proposed as the main biosynthetic pathway for AEA. First, phosphatidylethanolamine, a membrane phospholipid, is converted to N-acyl- phosphatidylethanolamine (NAPE) by a calcium-dependent $\mathrm{N}$-acyltransferase (NAT). Then, an NAPE-selective phospholipase D (NAPEPLD) catalyses NAPE to form N-acylethanolamines, such as AEA. For 2-AG, the major pathway also consists of a two-step process: diacylglycerol (DAG) is initially produced from inositol phospholipids by the phospholipase C enzyme, and subsequently hydrolysed to 2-AG by a diacylglycerol lipase (DAGL). Alternative enzymatic pathways also appear to be involved in the biosynthesis of both AEA and 2-AG. Following their release from depolarised post-synaptic neurons, endocannabinoids are regarded to act as retrograde messengers, and activate $\mathrm{CB}_{1}$ receptors on pre-synaptic terminals. Their overall effect may be excitatory or inhibitory, depending on a reduction in neurotransmitter release, mostly as the result of pre-synaptic inhibition of GABA or glutamatergic transmission (Figure 2) (4, 14, 27-29).

After activating cannabinoid receptors, endocannabinoids are removed from the extracellular space by a process of cellular uptake. Not much is known about the uptake of 2-AG, but a specific "endocannabinoid membrane transporter" appears to mediate the removal of AEA, although this has not yet been cloned $(14,28,30,31)$. Then, AEA is hydrolysed to arachidonic acid and ethanolamine in post-synaptic neurons, whereas 2-AG is hydrolysed to arachidonic acid and glycerol in pre-synaptic neurons, predominantly by the enzymes fatty acid amide hydrolase (FAAH) and monoacylglycerol lipase (MAGL), respectively. Accordingly, FAAH appears to terminate endocannabinoid action during synthesis, while MAGL seems to play role after receptor activation. The endocannabinoids AEA and 2-AG are also metabolised via oxidation by the enzymes cyclooxygenase (COX), lipooxygenase, and cytochrome P-450 (4, 14, 28, 29).

\section{MODULATION OF THE ENDOCANNABINOID SYSTEM}

The central side effects of exogenous cannabinoids, most of which are related to $\mathrm{CB}_{1}$ receptors in the central nervous system (CNS), directed researchers to look for alternative strategies. Peripherally restricted $\mathrm{CB}_{1}$ agonists and/or selective $\mathrm{CB}_{2}$ receptor agonists deserve attention, since they are expected to minimise unwanted $\mathrm{CNS}$ effects mediated via $\mathrm{CB}_{1}$ receptors. There are reports indicating that selective peripheral $\mathrm{CB}_{1}$ agonists are effective in controlling conditions, such as chronic neuropathic pain and spasticity in multiple sclerosis $(32,33)$; however, no evidence of analgesic efficacy was observed for a peripherally acting $\mathrm{CB}_{1} / \mathrm{CB}_{2}$ receptor agonist in the human capsaicin pain model (34). Selective $\mathrm{CB}_{2}$ receptor agonists have also undergone clinical trials and found to be beneficial, but unwanted effects, such as immune depression, have prevented their use in the clinic $(35,36)$. Combining low doses of cannabinoids with other analgesics, such as opioids or NSAIDs, is also promising. Reducing the cannabinoid and opioid/NSAID dose needed may provide an advantageous treatment strategy by enhancing pain relief whilst minimising the incidence of adverse effects $(6,7,37)$. 
Elevating endocannabinoid levels appears to be the most striking strategy for developing analgesic drugs with cannabinoid properties but devoid of central psychotropic effects (3840). During pain states, endocannabinoids are only synthesised and metabolised in the CNS structures involved in pain transmission and modulation. Thus, augmenting endocannabinoid levels in these structures will only effect $C B$ receptors in these areas and possibly reduce central side effects. Inhibition of the degradative enzymes FAAH and MAGL, and inhibition of endocannabinoid cellular uptake are the pharmacological strategies used to modulate the endocannabinoid system and elevate endocannabinoid levels locally $(3,5,22,38,40)$.

Fatty acid amide hydrolase inhibitors, such as URB597 and OL135, are shown to be effective at reducing sensitivity to pain in acute and chronic experimental pain models $(41,42)$. However, in a recent clinical trial, PF-04457845, an irreversible FAAH inhibitor, failed to induce effective analgesia in patients with knee osteoarthritis (43). It is noteworthy that AEA, at higher concentrations, activates TRPV1 channels, which are known to be involved in nociception, and that the COX pathway represents an alternative metabolic route for AEA. Thus, COX-1 and COX-2 inhibitors, and TRPV1 antagonists seem to be potential second targets to combine with FAAH inhibitors $(22,39,44)$. Dual FAAH/TRPV1 blockers, such as Narachidonoyl-serotonin (AA-5-HT) and OMDM198, are also efficacious in animal studies, but this multi-target strategy has not yet reached the clinic $(45,46)$.

Inhibition of MAGL using pharmacological agents, such as URB602, JZL184 and OMDM169, also elicits anti-nociceptive activity in experimental models, but tolerance may develop with fully effective doses of MAGL inhibitors (47). Dual FAAH/MAGL inhibition and using peripherally restricted inhibitors of FAAH and MAGL are also among the promising strategies $(38,39,48)$. Moving to the inhibition of endocannabinoid cellular uptake, there are some potential therapeutic effects observed with the use of membrane transporter inhibitors in animal models $(30,38,40)$. This approach has once again gained attention after the recent discovery of FAAH-like anandamide transporter (49), but clinical research remains to be determined.

It is worth mentioning that endocannabinoid system seems to mediate anti-nociceptive effects of 2 analgesics used worldwide, paracetamol and dipyrone. Paracetamol is metabolised in the brain by FAAH into AM404, which reinforces the activity of the descending serotonergic system through the endocannabinoid system via $\mathrm{CB}_{1}$ receptors $(50,51)$. FAAH also appears to be responsible for the formation of two novel arachidonyl-conjugated metabolites of dipyrone (52). Metabolites of these classical analgesics then possibly activate $\mathrm{CB}$ receptors or inhibit endocannabinoid metabolism (53-55), but clinical research is needed to determine how many of these findings also apply to humans.

\section{CONCLUSION}

The discovery of $\mathrm{CB}_{1}$ and $\mathrm{CB}_{2}$ receptors, their endogenous ligands (endocannabinoids), and the processes responsible for the biosynthesis, release, transport and metabolism of these compounds were a huge help in understanding the role of endocannabinoids in various physiological and pathological conditions, including pain modulation. Elevating endocannabinoid levels locally by the inhibition of endocannabinoid degrading enzymes, FAAH and MAGL, using pharmacological agents, and thereby reducing the unwanted central effects of exogenous cannabinoids, also made an additional contribution to this knowledge. Some of the most important future directions in this field are: (i) developing peripherally restricted $\mathrm{CB}_{1}$ agonists, (ii) inventing new $\mathrm{CB}_{2}$ agonists, (iii) combining cannabinoids with other analgesics, and (iv) elevating endocannabinoid levels using multi-target drugs such as FAAH/ MAGL, FAAH (MAGL)/COX and FAAH (MAGL)/TRPV1 dual blockers. Clinical trials will demonstrate the value of these approaches.

Ethics Committee Approval: N/A.

Informed Consent: N/A.

Peer-review: Internally peer-reviewed.

Acknowledgements: I wish to thank Prof. Hakan Karadağ for drawing figures.

Conflict of Interest: No conflict of interest was declared by the authors.

Financial Disclosure: The author declared that this study has received no financial support.

\section{REFERENCES}

1. Pertwee RG. Cannabinoid receptors and pain. Prog Neurobiol 2001;63:569-611. [CrossRef]

2. Walker JM, Huang SM. Cannabinoid analgesia. Pharmacol Ther 2002;95:127-35. [CrossRef]

3. Di Marzo V. Targeting the endocannabinoid system: to enhance or reduce? Nat Rev Drug Discov 2008;7:438-55. [CrossRef]

4. Guindon J, Hohmann AG. The endocannabinoid system and pain. CNS Neurol Disord Drug Targets 2009;8:403-21. [CrossRef]

5. Pertwee RG. Targeting the endocannabinoid system with cannabinoid receptor agonists: pharmacological strategies and therapeutic possibilities. Philos Trans R Soc Lond B Biol Sci 2012;367:3353-63. [CrossRef]

6. Ulugol A, Ozyigit F, Yesilyurt O, Dogrul A. The additive antinociceptive interaction between WIN 55,212-2, a cannabinoid agonist, and ketorolac. Anesth Analg 2006;102:443-7. [CrossRef]

7. Gunduz O, Karadag HC, Ulugol A. Synergistic anti-allodynic effects of nociceptin/orphanin FQ and cannabinoid systems in neuropathic mice. Pharmacol Biochem Behav 2011;99:540-4. [CrossRef]

8. Dogrul A, Gul H, YildIz O, Bilgin F, Guzeldemir ME. Cannabinoids blocks tactile allodynia in diabetic mice without attenuation of its antinociceptive effect. Neurosci Lett 2004;368:82-6. [CrossRef] 
9. Ulugol A, Karadag HC, Ipci Y, Tamer M, Dokmeci I. The effect of WIN $55,212-2$, a cannabinoid agonist, on tactile allodynia in diabetic rats. Neurosci Lett 2004;371:167-70. [CrossRef]

10. Munro S, Thomas KL, Abushaar M. Molecular Characterization of a peripheral receptor for cannabinoids. Nature 1993;365:61-5. [CrossRef]

11. Matsuda LA, Lolait SJ, Brownstein MJ, Young AC, Bonner TI. Structure of a cannabinoid receptor and functional expression of the cloned Cdna. Nature 1990;346:561-4. [CrossRef]

12. Dogrul A, Seyrek M, Yalcin B, Ulugol A. Involvement of descending serotonergic and noradrenergic pathways in CB1 receptor-mediated antinociception. Prog Neuropsychopharmacol Biol Psychiatry 2012;38:97105. [CrossRef]

13. Dogrul A, Seyrek M, Yalcin B, Ulugol A. Involvement of serotonergic system in cannabinoid analgesia. In: Van Bockstaele EJ, editor. Endocannabinoid regulation of monoamines in psychiatric and neurological disorders. New York: Springer; 2013:277-95. [CrossRef]

14. Guindon J, Beaulieu P, Hohmann AG. Pharmacology of the cannabinoid system. In: Beaulieu P, Lussier D, Porreca F, Dickenson AH, editors. Pharmacology of pain. Seattle: IASP Press; 2010:6.

15. Richardson JD. Cannabinoids modulate pain by multiple mechanisms of action. J Pain 2000;1:2-14. [CrossRef]

16. Manzanares J, Julian MD, Carrascosa A. Role of the cannabinoid system in pain control and therapeutic implications for the management of acute and chronic pain episodes. Curr Neuropharmacol 2006;4:239-57. [CrossRef]

17. Millan MJ. Descending control of pain. Prog Neurobiol 2002;66:355474. [CrossRef]

18. Meng ID, Manning BH, Martin WJ, Fields HL. An analgesia circuit activated by cannabinoids. Nature 1998;395:381-3. [CrossRef]

19. Dogrul A, Gul H, Akar A, YildIz O, Bilgin F, Guzeldemir E. Topical cannabinoid antinociception: synergy with spinal sites. Pain 2003;105:11-6. [CrossRef]

20. Malan TP, Ibrahim MM, Vanderah TW, Makriyannis A, Porreca F. Inhibition of pain responses by activation of $\mathrm{CB} 2$ cannabinoid receptors. Chemistry and Physics of Lipids 2002;121:191-200. [CrossRef]

21. Izzo AA, Borrelli F, Capasso R, Di Marzo V, Mechoulam R. Non-psychotropic plant cannabinoids: new therapeutic opportunities from an ancient herb. Trends Pharmacol Sci 2009;30:515-27. [CrossRef]

22. Starowicz K, Di Marzo V. Non-psychotropic analgesic drugs from the endocannabinoid system: "Magic bullet" or "multiple-target" strategies? Eur J Pharmacol 2013;716:41-53. [CrossRef]

23. Wright MJ, Vandewater SA, Taffe MA. Cannabidiol attenuates deficits of visuospatial associative memory induced by Delta 9tetrahydrocannabinol. Brit J Pharmacol 2013;170:1365-73. [CrossRef]

24. Sastre-Garriga J, Vila C, Clissold S, Montalban X. THC and CBD oromucosal spray (Sativex (R)) in the management of spasticity associated with multiple sclerosis. Expert Rev Neurother 2011;11:627-37. [CrossRef]

25. Wang T, Collet JP, Shapiro S, Ware MA. Adverse effects of medical cannabinoids: a systematic review. Can Med Assoc J 2008;178:1669-78. [CrossRef]

26. Toth C, Mawani S, Brady S, Chan C, Liu CX, Mehina E, et al. An enriched-enrolment, randomized withdrawal, flexible-dose, double-blind, placebo-controlled, parallel assignment efficacy study of nabilone as adjuvant in the treatment of diabetic peripheral neuropathic pain. Pain 2012;153:2073-82. [CrossRef]

27. Zogopoulos P, Vasileiou I, Patsouris E, Theocharis SE. The role of endocannabinoids in pain modulation. Fund Clin Pharmacol 2013;27:64-80.

28. Cascio MG. PUFA-derived endocannabinoids: an overview. P Nutr Soc 2013;72:451-9. [CrossRef]

29. Di Marzo V. Endocannabinoids: synthesis and degradation. Rev Physiol Biochem Pharmacol 2008;160:1-24.

30. Fowler CJ. Anandamide uptake explained? Trends Pharmacol Sci 2012;33:181-5. [CrossRef]
31. Jhaveri MD, Richardson D, Chapman V. Endocannabinoid metabolism and uptake: novel targets for neuropathic and inflammatory pain. Brit $J$ Pharmacol 2007;152:624-32. [CrossRef]

32. Karst M, Salim K, Burstein S, Conrad I, Hoy L, Schneider U. Analgesic effect of the synthetic cannabinoid CT-3 on chronic neuropathic pain: a randomized controlled trial. JAMA 2003;290:1757-62. [CrossRef]

33. Pryce G, Visintin C, Ramagopalan SV, Al-Izki S, De Faveri LE, Nuamah RA, et al. Control of spasticity in a multiple sclerosis model using central nervous system-excluded CB1 cannabinoid receptor agonists. FASEB J 2014;28:117-30. [CrossRef]

34. Kalliomaki J, Annas P, Huizar K, Clarke C, Zettergren A, Karlsten $\mathrm{R}$, et al. Evaluation of the analgesic efficacy and psychoactive effects of AZD1940, a novel peripherally acting cannabinoid agonist, in human capsaicin-induced pain and hyperalgesia. Clin Exp Pharmacol $P$ 2013;40:212-8. [CrossRef]

35. Ostenfeld T, Price J, Albanese M, Bullman J, Guillard F, Meyer I, et al. A randomized, controlled study to investigate the analgesic efficacy of single doses of the cannabinoid receptor-2 agonist GW842166, ibuprofen or placebo in patients with acute pain following third molar tooth extraction. Clin J Pain 2011;27:668-76. [CrossRef]

36. Atwood BK, Straiker A, Mackie K. CB2: therapeutic target-in-waiting. Prog Neuropsychopharmacol Biol Psychiatry 2012;38:16-20. [CrossRef]

37. Smith PA, Selley DE, Sim-Selley LJ, Welch SP. Low dose combination of morphine and [Delta]9-tetrahydrocannabinol circumvents antinociceptive tolerance and apparent desensitization of receptors. Eur J Pharmacol 2007;571:129-37. [CrossRef]

38. Pertwee RG. Elevating endocannabinoid levels: pharmacological strategies and potential therapeutic applications. Proc Nutr Soc 2014;73:96105. [CrossRef]

39. Maione S, Costa B, Di Marzo V. Endocannabinoids: a unique opportunity to develop multitarget analgesics. Pain 2013;154:S87-93. [CrossRef]

40. Piscitelli F, Di Marzo V. "Redundancy" of Endocannabinoid Inactivation: New Challenges and Opportunities for Pain Control. ACS Chem Neurosci 2012;3:356-63. [CrossRef]

41. Naidu PS, Kinsey SG, Guo TL, Cravatt BF, Lichtman AH. Regulation of inflammatory pain by inhibition of fatty acid amide hydrolase. $J$ Pharmacol Exp Ther 2010;334:182-90. [CrossRef]

42. Caprioli A, Coccurello R, Rapino C, Di Serio S, Di Tommaso M, Vertechy $\mathrm{M}$, et al. The novel reversible fatty acid amide hydrolase inhibitor ST4070 increases endocannabinoid brain levels and counteracts neuropathic pain in different animal models. J Pharmacol Exp Ther 2012;342:188-95. [CrossRef]

43. Huggins JP, Smart TS, Langman S, Taylor L, Young T. An efficient randomised, placebo-controlled clinical trial with the irreversible fatty acid amide hydrolase-1 inhibitor PF-04457845, which modulates endocannabinoids but fails to induce effective analgesia in patients with pain due to osteoarthritis of the knee. Pain 2012;153:1837-46. [CrossRef]

44. Fowler CJ, Naidu PS, Lichtman A, Onnis V. The case for the development of novel analgesic agents targeting both fatty acid amide hydrolase and either cyclooxygenase or TRPV1. Brit J Pharmacol 2009;156:412-9. [CrossRef]

45. Morera E, De Petrocellis L, Morera L, Moriello AS, Ligresti A, Nalli $\mathrm{M}$, et al. Synthesis and biological evaluation of piperazinyl carbamates and ureas as fatty acid amide hydrolase (FAAH) and transient receptor potential (TRP) channel dual ligands. Bioorg Med Chem Lett 2009;19:6806-9. [CrossRef]

46. Costa B, Bettoni I, Petrosino S, Comelli F, Giagnoni G, Di Marzo V. The dual fatty acid amide hydrolase/TRPV1 blocker, N-arachidonoylserotonin, relieves carrageenan-induced inflammation and hyperalgesia in mice. Pharmacol Res 2010;61:537-46. [CrossRef]

47. Schlosburg JE, Blankman JL, Long JZ, Nomura DK, Pan B, Kinsey SG, et al. Chronic monoacylglycerol lipase blockade causes functional antagonism of the endocannabinoid system. Nat Neurosci 2010;13:1113U111. [CrossRef] 
48. Niphakis MJ, Johnson DS, Ballard TE, Stiff C, Cravatt BF. O-hydroxyacetamide carbamates as a highly potent and selective class of endocannabinoid hydrolase inhibitors. ACS Chem Neurosci 2012;3:418-26. [CrossRef]

49. Fu J, Bottegoni G, Sasso O, Bertorelli R, Rocchia W, Masetti M, et al. A catalytically silent FAAH-1 variant drives anandamide transport in neurons. Nat Neurosci 2012;15:64-U82. [CrossRef]

50. Hogestatt ED, Jonsson BAG, Ermund A, Andersson DA, Bjork H, Alexander JP, et al. Conversion of acetaminophen to the bioactive Nacylphenolamine AM404 via fatty acid amide hydrolase-dependent arachidonic acid conjugation in the nervous system. J Biol Chem 2005;280:31405-12. [CrossRef]

51. Mallet C, Daulhac L, Bonnefont J, Ledent C, Etienne M, Chapuy E, et al. Endocannabinoid and serotonergic systems are needed for acetaminophen-induced analgesia. Pain 2008;139:190-200. [CrossRef]
52. Rogosch T, Sinning C, Podlewski A, Watzer B, Schlosburg J, Lichtman $\mathrm{AH}$, et al. Novel bioactive metabolites of dipyrone (metamizol). Bioorg Med Chem 2012;20:101-7. [CrossRef]

53. Elmas P, Ulugol A. Involvement of cannabinoid CB1 receptors in the antinociceptive effect of dipyrone. J Neural Transm 2013;120:1533-8. [CrossRef]

54. Ottani A, Leone S, Sandrini M, Ferrari A, Bertolini A. The analgesic activity of paracetamol is prevented by the blockade of cannabinoid CB1 receptors. Eur J Pharmacol 2006;531:280-1. [CrossRef]

55. Escobar W, Ramirez K, Avila C, Limongi R, Vanegas H, Vazquez E. Metamizol, a non-opioid analgesic, acts via endocannabinoids in the PAG-RVM axis during inflammation in rats. Eur J Pain 2012;16:67689. [CrossRef] 